role in sustainable agriculture systems in the future. The IP40 Black material shows great promise as a soil mulch and would go a long way towards solving the disposal problem created when non-degradable black plastic mulch is used in annual and perennial fruit and vegetable production. Variations in the carbon black additive or in colors may modify the degradation properties of the material to make it more useful forvarious production practices in the future.

\section{Literature cited}

Albregts, E.E. and C.M. Howard. 1972. Comparison of polyethylene and polyethylene-coated bio-degradable paper mulches on strawberries. HortScience 7:568-569.

Anderson, D.F., M.A. Garisto, J.C. Bourrut, M.W. Schonbeck, R. Jaye, A. Wurzberger, and R. DeGregorio. 1995. Evaluation of a paper mulch made from recycled materials as an alternative to plastic film mulch for vegetables. J. Sustainable Agr. 7:39-61.

Edmond,J.B. 1929. Mulch paper for vegetable crops is tested. Mich. Agr. Expt. Sta. Bul. 11: 115-117.

Flint, L.H. 1928. Crop-plant stimulation with paper mulch. USDA Tech. Bul. 75:1-20.

Gomez, K.A. and A.A. Gomez. 1984. Statistical procedures for agricultural research. Wiley, New York.

Greer, L. and J.M. Dole. 2003. Aluminum foil, aluminum-painted, plastic, and degradable mulches increase yields and decrease insect-vectored diseases of vegetables. HortTechnology. 13:276-284.

Hutchins, A.E. 1933. Mulch papers in vegetable production. Minn. Agr. Expt. Sta. Bul. 298.

Peavy, W.S. 1973. Paper mulch for muskmelons in low rainfall areas. Proc. Nat. Agr. Plast. Conf. 11:192.

Pritts, M. and D. Handley (eds.). 1988. Strawberry production guide. N.E. Region. Agr. Eng. Ser. Bul. NRAES-88. Cornell Univ., Ithaca, N.Y.

Pritts, M.P. and M. Kelly. 2001. Early season weed competition reduces yield of newly planted matted row strawberries. HortScience. 36:729-731.

Sanford, J.C., D.K. Ourecky, and J.E. Reich. 1985. 'Jewel' strawberry. New York's Food Life Sci. Bul. 114. New York State Agr. Expt. Sta., Geneva, N.Y.

Shogren, R.L. 2000. Biodegradable mulches from renewable resources. J. Sustainable Agr. 16:33-47.

Smith, A. 1931. Effect of paper mulches on soil temperature, soil moisture, and yields of crops. Hilgardia 6:159-201.

Yang, S. 1999. Degradable plastic films for agricultural applications in Taiwan. Natl. Agr. Plastics Congr. Proc. 28:4-9.

\title{
Managing Orchard Floor Vegetation in Flood-irrigated Citrus Groves
}

\author{
Glenn C. Wright, ${ }^{1}$ \\ William B. McCloskey, ${ }^{2}$ and \\ Kathryn C. Taylor ${ }^{3}$
}

Additional INDEX WORDS. chemical weed control, citrus limon, citrus sinensis, cover crops, herbicides, lemon, mechanical weed control, orange

Summary. Several orchard floor management strategies were evaluated beginning in Fall 1993 in a 'Limoneira 8A Lisbon' lemon (Citrus limon) grove on the Yuma Mesa in Yuma, Ariz. and in a 'Valencia' orange (Citrus sinensis) grove at the University of Arizona Citrus Agricultural Center, Waddell, Ariz. At Yuma, disking provided acceptable weed control except underneath the tree canopies where bermudagrass (Cynodon dactylon), purple nutsedge (Cyperus rotundus), and other weed species survived. Mowing the orchard floor suppressed broadleaf weed species allowing the spread of grasses, primarily bermudagrass. Preemergence (norflurazon and oryzalin) and postemergence (glyphosate and sethoxydim) herbicides were used to control weeds in the clean culture treatment in Yuma. After three harvest seasons (1994-95 through 1996-97), the cumulative yield of the clean culture treatment was $385 \mathrm{~kg}(848.8 \mathrm{lb})$ per tree, which was significantly greater than the $\mathbf{3 3 2}$ $\mathrm{kg}(731.9 \mathrm{lb})$ and $320 \mathrm{~kg}(705.5 \mathrm{lb})$ per tree harvested in the disking and mowing treatments, respectively. In addition, the clean culture treatment had a significantly greater percentage of fruit in the $\mathbf{1 1 5}$ and larger size category at the first harvest of the 1995-96 season than either the disk

The authors would like to thank the Arizona Citrus Research Council and the Yuma County Pest Abatement District for their financial assistance in completing this project. We would also like to thank Glen Curtis Incorporated for their cooperation, and technicians Philip Tilt, Gary Dixon, and Heather Geitzenauer for their invaluable assistance.

${ }^{1}$ Associate specialist, Department of Plant Sciences, Yuma Mesa Agriculture Center, University of Arizona, 2186 W. County 15th St., Somerton, AZ 85350. ${ }^{2}$ Associate specialist, Department of Plant Sciences, Forbes 303, University of Arizona, Tucson, AZ 85721. ${ }^{3}$ Assistant professor. Current address: University of Georgia, Horticulture Department, Southeastern Fruit and Tree Nut Laboratory, 21 Dunbar Rd, Byron, GA 31008 . or mow treatments. At Waddell, the management strategies compared were clean culture (at this location only postemergence herbicides were used), mowing of resident weeds with a vegetation-free strip in the tree row, and a 'Salina' strawberry clover (Trifolium fragiferum) cover crop with a vegetation-free strip. The cumulative 3-year yield (1994-95 through 1996-97) of the clean culture treatment was 131 $\mathrm{kg}(288.8 \mathrm{lb})$ per tree, which was significantly greater then the $110 \mathrm{~kg}$ $(242.5 \mathrm{lb})$ per tree yield of the mowed resident weed treatment. The yield of the strawberry clover treatment, $115 \mathrm{~kg}(253.5 \mathrm{lb})$ of oranges per tree, was not significantly different from the other two treatments. The presence of cover crops or weeds on the orchard floor was found to have beneficial effects on soil nitrogen and soil organic matter content, but no effect on orange leaf nutrient content. The decrease in yield in the disked or mowed resident weed treatments compared to the clean culture treatment in both locations was attributed to competition for water.

$M$ anaging weeds on orchard floors in flood-irrigated Arizona citrus groves can be accomplished by disking, mowing, applying pre- and postemergence herbicides, or by growing a cover crop. Weeds in flood-irrigated Arizona lemon groves have traditionally been managed by disking of the orchard floor (two to eight times per year) (Hilgeman and Rodney, 1961; Jordan and Day, 1973; personal observation by the authors in 2002). Disking is done in two directions (i.e., crossdisked), so that there is no herbicide-treated strip down the tree middle. Disking adequately controls weeds on the orchard floor except for nondisked areas underneath the tree canopies where bermudagrass, purple nutsedge, and other weeds survive. However, disking prunes tree roots near the soil surface reducing shallow root density compared to clean culture with herbicides (Hogue and Nielsen, 1987; Parker et al., 1993). Additionally, tree shallow root density under cover crops is often even less than in disked areas (Hogue and Nielsen, 1987; Parker et al., 1993). These shallow roots are the primary sites of water and nutrient uptake for the tree (Davies and Albrigo, 1994). Careless operation of equipment also results in broken branches and injured 
trunks that can provide an entry point for plant pathogens (Matheron et al., 1998). Disking increases the soil seed bank by burying weed seeds in the soil, inducing seed dormancy, and brings buried weed seeds to the surface exposing them to light, breaking seed dormancy and stimulating germination (Ross and Lembi, 1999). In the Yuma Mesa lemon production area, disking incorporates weed biomass into the soil that provides an ideal breeding habitat for the liohippelates eye gnat, (Liohippelates collusor) (Metcalf and Metcalf, 1993). The prevalence of disking and resulting large populations of this annoying pest resulted in the formation of a pest abatement district. Mowing weeds on the flood-irrigated orchard floor has not been widely practiced in Arizona because it leads to a grass sod which competes with the tree for water and nutrients and has other negative attributes such as reducing irrigation efficiency. Traditionally, preemergence herbicides have not been widely used in Arizona groves with sandy soils because flood irrigation can leach some herbicides such as bromacil, diuron, and simazine into the tree root zone causing injury (McCloskey and Maurer, 1997). In the early 1990s, when this experiment was initiated, glyphosate was not commonly used in citrus groves. Broadcast applications of postemergence herbicides, especially glyphosate, have only recently become used in flood-irrigated Arizona citrus groves as a replacement for disking (Knapp, 1999). Occasionally, foliar injury symptoms caused by glyphosate can be found at the base of tree canopies, but this injury does not affect tree yield (McCloskey and Wright, 1999).

Recently there has been renewed interest in using cover crops in Arizona citrus groves. Cover crops suppress weeds (Bordelon and Weller, 1997; Bradshaw and Lanini, 1995; Ross et al., 2001; Teasdale, 1996), increase water infiltration (Gomez et al., 2002; Merwin et al., 1994; Roberson et al., 1991; Walsh et al., 1996) and increase soil organic matter content (Bugg et al., 1991; Hogue and Neilsen, 1987; Merwin and Stiles, 1994). Cover crops have the potential to harbor beneficial predatory insects in citrus (GraftonCardwell etal., 1999) and other orchard crops (Altieri and Schmidt, 1986; Tedders, 1983). Irrigated cover crops can decrease soil and canopy temperatures (Hogue and Neilsen, 1987; McCloskey et al., 1996; Walsh et al., 1996). Legume species, used for cover crops, that can be adapted to citrus production practices, appear to have greater potential benefits than nonlegume broadleaf and grass cover crops or resident weed species because legumes add nitrogen to the soil (Sainju and Singh, 1997). Legume-derived nitrogen may increase nitrogen available for tree growth and fruit production thereby decreasing the requirement for nitrogen-fertilizer inputs (Marsh et al., 1996). Potential disadvantages of using cover crops in citrus and other perennial crops include reducing crop root and trunk growth (Bordelon and Weller, 1997; Hogue and Neilsen, 1987; Merwin and Stiles, 1994; Parker et al., 1993) and creating habitats where populations of phytophagus insects (Altieri and Schmidt, 1986), nematodes (Marks et al., 1973) and other pests may be sheltered (Merwin and Stiles, 1994). Other disadvantages include the difficulty in moving irrigation water through the cover crop in flood-irrigated basins, and increased risk of freeze damage caused by reducing the amount of bare soil that would normally act as a heat reservoir during the winter (Hilgeman and Rodney, 1961; Hogue and Neilsen, 1987)

The availability of less injurious herbicides for weed control, an increased awareness of the possibility that older herbicides and disking may injure trees, and financial payments from the Yuma County Pest Abatement District to reduce disking on the Yuma Mesa, prompted an investigation of alternative methods of orchard floor management. Thus, our objective was to compare tree crop responses to different methods of reducing weed population densities. The methods studied included traditional mechanical weed control strategies, newer, safer chemical alternatives and biological alternatives in the form of cover crops. To that end, tree yields, fruit packout, weed populations, leaf nutrient content, and soil characteristics were measured in the different methods used to reduce weed densities. These methods included the traditional practices of disking and mechanical mowing, the use of pre- and postemergence herbicides to maintain a weed-free orchard floor, and the use of a cover crop.

\section{Materials and methods}

YUMA MESA ORCHARD FLOOR MANAGEMENT STUDY. Treatments were initiated in the Fall 1993 in a 4-year-old, floodirrigated 'Limoneira 8A Lisbon' lemon grove on the Yuma Mesa [ soil series: Superstition Sand, a sandy, mixed, hyperthermic Typic Calciothrids (Barmore, 1980) with a $\mathrm{pH}$ of 7.9 to 8.4.]. The trees were about $3.0 \mathrm{~m}(10 \mathrm{ft})$ in height at the start of the experiment and were planted on $6.1-\mathrm{m}(20-\mathrm{ft})$ centers. The four treatments were arranged in the grove using a randomized complete block experimental design with four replications. Each treatment unit consisted of a row of 30 trees with treatments applied on row middles on both sides separated from adjacent treatment units by a row of trees that provided a buffer. Weed control in the grove before the beginning of the experiment was accomplished solely by frequent disking. The entire grove was disked in October 1993 before the initiation of the experiment. The original four methods of weed control evaluated in the experiment were mowing, chemical mowing with reduced postemergence herbicide rates, clean culture using preand postemergence herbicides, and disking (the grower standard against which the other treatments were compared). Cultural operations in each treatment are listed in Table 1. Disked plots were treated when weed height exceeded 0.6 to $0.9 \mathrm{~m}(2$ to $3 \mathrm{ft})$. In 1996, the experiment was completed after two disking operations. Mowed plots were treated when the broadleaf weed height exceeded 0.6 to $0.9 \mathrm{~m}$. Frequency of mowing decreased as the bermudagrass density increased due to suppression of broadleaf weeds. Preemergence herbicides were applied to the clean culture plots in November 1993, November 1994, and October 1995. The need for postemergence spot treatments of weed escapes in the clean culture plots was reduced over time as germinating weed seeds were killed by the preemergence herbicides and the soil-surface seed bank was not replenished by disking or new seed production.

The chemical mow treatment did not provide effective weed control and the populations of several undesirable weed species began to increase. In addition, rank growth of weeds began to restrict access to the treatment plots and hinder additional chemical mow applications; therefore, on 26 July 1994 this treatment was mowed and on 8 Apr. 1994 glyphosate was applied at 7.0 L.ha-1 (3 qt/acre) to terminate the treatment. Plots assigned to the 
Table 1. Herbicide and cultural operations by treatment in the Yuma Mesa (Yuma, Ariz.) orchard floor management study. Entire orchard was disked in October 1993. Herbicides were broadcast applied unless otherwise noted.

\begin{tabular}{|c|c|}
\hline Treatment & Date and treatment details ${ }^{z}$ \\
\hline \multirow[t]{3}{*}{ Mow } & Mowed in 1994 on 16 Mar., 9 May, 26 July, and 15 Dec. \\
\hline & Mowed in 1995 on 30 Mar., 28 June, and 13 Sept. \\
\hline & Mowed in 1996 on 7 May and 28 Aug. \\
\hline \multirow[t]{3}{*}{ Disk } & Disked in 1994 on 16 Mar., 10 June, and 19 Oct. \\
\hline & Disked in 1995 on 30 Mar., 28 June, 13 Sept., and 27 Oct. \\
\hline & Disked in 1996 on 7 May and 24 Aug. \\
\hline \multirow{4}{*}{ Chemical mow } & 11 Mar. 1994: sprayed $0.42 \mathrm{~kg} \cdot h \mathrm{~h}^{-1}$ a.e. glyphosate $+0.5 \% \mathrm{v} / \mathrm{v}$ NIS \\
\hline & 12 May 1994: sprayed $0.42 \mathrm{~kg} \cdot \mathrm{ha}^{-1}$ a.e. glyphosate $+0.5 \% \mathrm{v} / \mathrm{v}$ NIS \\
\hline & 26 July 1994: mechanically mowed \\
\hline & 4 Aug. 1994: sprayed $2.52 \mathrm{~kg} \cdot \mathrm{ha}^{-1}$ a.e. glyphosate $+0.5 \% \mathrm{v} / \mathrm{v}$ NIS to terminate treatment \\
\hline \multirow[t]{10}{*}{ Clean culture } & 3 Nov. 1993: sprayed $3.34 \mathrm{~kg} \cdot \mathrm{ha}^{-1}$ a.i. norflurazon $+3.36 \mathrm{~kg} \cdot \mathrm{ha}^{-1}$ a.i. oryzalin \\
\hline & 12 May 1994: spot sprayed $2.70 \mathrm{~g} \cdot \mathrm{L}^{-1}$ a.i. sethoxydim + 1\% COC to control bermudagrass under the tree canopies \\
\hline & 18 May 1994: spot sprayed $7.19 \mathrm{~g} \cdot \mathrm{L}^{-1}$ a.e. glyphosate $+0.5 \% \mathrm{v} / \mathrm{v}$ NIS to control weed patches between trees \\
\hline & 4 Aug. 1994: sprayed $2.52 \mathrm{~kg} \cdot \mathrm{ha}^{-1}$ a.e. glyphosate $+0.5 \% \mathrm{v} / \mathrm{v}$ NIS between tree rows \\
\hline & 4 Aug. 1994: spot sprayed $2.70 \mathrm{~g} \cdot \mathrm{L}^{-1}$ a.i. sethoxydim $+1 \%$ COC to control bermudagrass under the tree canopies \\
\hline & $\begin{array}{l}7 \text { Nov. 1994: sprayed } 2.24 \mathrm{~kg} \cdot \mathrm{ha}^{-1} \text { a.i. norflurazon }+2.24 \mathrm{~kg} \cdot \mathrm{ha}^{-1} \text { a.i. oryzalin }+0.84 \mathrm{~kg} \cdot \mathrm{ha}^{-1} \text { a.e. glyphosate }+0.5 \% \mathrm{v} / \mathrm{v} \\
\text { NIS to area between tree rows }\end{array}$ \\
\hline & $\begin{array}{l}15 \text { Dec. 1994: sprayed } 2.80 \mathrm{~kg} \cdot \mathrm{ha}^{-1} \text { a.i. norflurazon }+2.24 \mathrm{~kg} \cdot \mathrm{ha}^{-1} \text { a.i. oryzalin }+0.84 \mathrm{~kg} \cdot \mathrm{ha} \mathrm{h}^{-1} \text { a.e. glyphosate }+ \\
0.5 \% \mathrm{v} / \mathrm{v} \text { NIS to area between trees within a tree row }\end{array}$ \\
\hline & $\begin{array}{l}25 \text { June 1995: spot sprayed solution containing } 2.70 \mathrm{~g} \cdot \mathrm{L}^{-1} \text { a.i. sethoxydim }+1 \% \text { COC to control bermudagrass under } \\
\text { the tree canopies }\end{array}$ \\
\hline & $\begin{array}{l}25 \text { June 1995: spot sprayed solution containing } 7.19 \mathrm{~g} \cdot \mathrm{L}^{-1} \text { a.e. glyphosate }+0.5 \% \mathrm{v} / \mathrm{v} \text { NIS to control weed patches } \\
\text { between trees }\end{array}$ \\
\hline & $\begin{array}{l}\text { 31 Oct. 1995: sprayed } 2.80 \mathrm{~kg} \cdot \mathrm{ha}^{-1} \text { a.i. norflurazon }+2.24 \mathrm{~kg} \cdot \mathrm{ha}^{-1} \text { a.i. oryzalin }+0.84 \mathrm{~kg} \cdot \mathrm{ha}^{-1} \text { a.e. glyphosate }+0.5 \% \\
\text { v/v NIS to entire orchard floor. }\end{array}$ \\
\hline
\end{tabular}

${ }^{\mathrm{z}} 1.00 \mathrm{~kg} \cdot \mathrm{ha}^{-1}=0.892 \mathrm{lb} / \mathrm{acre} ; 1.00 \mathrm{~g} \cdot \mathrm{L}^{-1}=0.134 \mathrm{oz} / \mathrm{gal}=0.835 \mathrm{lb} / 100$ gal., a.e. $=$ acid equivalent, COC $=$ crop oil concentrate, NIS $=$ nonionic surfactant.

chemical mow treatment were disked to prepare a seedbed, planted with 'Salina' strawberry clover on 28 Oct. 1994, and irrigated in an attempt to establish a cover crop. Emergence and establishment of strawberry clover was unsuccessful.

The preemergence herbicides, oryzalin [Surflan (Dow AgroSciences, Indianapolis)] and norflurazon [Solicam (Syngenta Crop Protection, Greensboro, N.C.)] were used in this study because citrus injury caused by these herbicides is rare. The preemergence herbicides and some postemergence applications of glyphosate [Roundup Original or Roundup Ultra (Monsanto, St. Louis)] were broadcast to the entire orchard floor using flat fan nozzles operated at low pressure 138.0 to $172.5 \mathrm{kPa}$ ( 20 to $25 \mathrm{lb} /$ inch $^{2}$ ) and a tractor-pulled sprayer. Spot treatments of glyphosate and sethoxydim [Poast (BASF Ag Products, Research Park Triangle, N.C.)] were applied using flat fan nozzles at low pressure in the clean culture treatment to control weed patches between tree rows and to control bermudagrass under the tree canopies. All postemergent herbicides were applied with the appropriate adjuvant, either nonionic surfactant (NIS) or crop oil concentrate (COC). In addition, the entire experiment was mowed on 7 Dec. 1994 to shred prunings that hindered applying herbicides to the orchard floor within the tree row.

Weed species composition and populations were estimated on 15 Dec. 1993, 24 Jan. 1994, 28 Mar. 1994, 7 June 1994, 22 July 1994, 21 Oct. 1994, 22 Feb. 1995, 9 May 1995, 1 Sept. 1995, 8 Jan. 1996, 24 Apr. 1996, 31 July 1996, and 29 Oct. 1996. Early weed counts were made in four locations along a tree row by counting the number of plants of each species in a $0.25 \mathrm{~m}^{2}(2.691$ $\mathrm{ft}^{2}$ ) (15 Dec. 1993) or $0.5 \mathrm{~m}^{2}$ (5.38 $\mathrm{ft}^{2}$ ) subplot (24 Jan. 1994, 28 Mar. 1994 and 7 June 1994). Data from these counts are expressed as weeds per square meter. When this method became too burdensome because of dense weed populations, subsequent weed populations were assessed by visually estimating the percentage ground cover of each species in the $37.2 \mathrm{~m}^{2}\left(400 \mathrm{ft}^{2}\right)$ area delimited by four trees (i.e., a square). Percentage ground cover could potentially exceed $100 \%$ because plants of different species covered the same surface area.

Trees were grown under commercial production practices common to southwestern Arizona. Trees were flood irrigated, and received about $7500 \mathrm{~L} \cdot \mathrm{ha}^{-1}$ (801.8 gal/acre) of water annually, provided in up to 20 applications. Irrigation was typically applied every 10 to $21 \mathrm{~d}$ depending on the time of year. Trees were fertilized annually with $304.9 \mathrm{~kg} \cdot \mathrm{ha}^{-1}(272$ $\mathrm{lb} / \mathrm{acre}$ ) nitrogen in the form of urea ammonium nitrate $(32 \mathrm{~N}-0 \mathrm{P}-0 \mathrm{~K})$, and with one annual application of $84.1 \mathrm{~kg} \cdot \mathrm{ha}^{-1}$ (75 lb/acre) ammonium phosphate $(10 \mathrm{~N}-14.9 \mathrm{P}-0 \mathrm{~K})$. Foliar applications of iron, manganese and zinc were applied as needed, typically once or twice a year in the spring. Insects, chiefly citrus thrips (Scirtothrips citri), were controlled using formetanate hydrochloride and dimethoate with application timings determined by scouting.

Timing of fruit harvest and nature of harvest [ring picking or strip (total) harvest] was specified by each contracting packinghouse and was based on market conditions. Professional pickers hand-harvested lemons from each plot. For the 29 Sept. 1994, 4 Oct. 1995, and 12 Dec. 1995 harvests, the pickers selectively picked only the fruit on the tree with a diameter greater than $52.4 \mathrm{~mm}$ (2.06 inches), using a metal ring (the ring pick-harvest). This diameter corresponds to a fruit size of 165 fruit per $17-\mathrm{kg}$ (37.5-lb) box. For the 3 Oct. 1996 harvest, pickers used a ring with a diameter of $49.2 \mathrm{~mm}$ ( 1.94 
inches), corresponding to a fruit size of 200 fruit per box. Fruit that were too large to pass through the ring were harvested. For the final harvest of each year (2 Dec. 1994, 28 Feb. 1996, and 6 Dec. 1996), all the remaining fruit was picked (the strip-harvest). Fruit from each row was harvested into the standard 544.3-kg (1200-lb) wooden bin, transported to the packinghouse, then weighed, and processed separately through automatic sizers to give fruit diameter (packout). Yield data from the two or three harvests of 30 trees per plot were combined to give total annual yields per plot. Mean treatment yields were calculated from the four replicate plots per treatment.

Leaves were collected in August 1994 and 1995 from three trees in each treatment plot in each block and pooled by treatment and block. For analysis of nitrogen, phosphorus, potassium, and sulfur, the samples were dried in a forced air oven at $60^{\circ} \mathrm{C}\left(140.0^{\circ} \mathrm{F}\right)$ and ground through a 40 -mesh screen before wet digestion. The digestion for nitrogen analysis was as described by Mitchell (1972). A nitric acid digestion method was used to prepare the leaf samples for potassium, phosphorus, and sulfur analysis (Perkin-Elmer, 1982). Nitrogen, phosphorus, and sulfur were analyzed colorimetrically (Mitchell, 1972; Jackson, 1958); and potassium was determined using atomic absorption spectrometry at $766.5 \mathrm{~nm}$ (model 3100; Perkin-Elmer Analytical Instruments, Shelton, Conn.).

Data were analyzed using SPSS statistical package (SPSS Inc., Chicago). Analysis of variance tests and means separation tests were used where appropriate. Some of the weed count and percent ground cover data violated the assumptions of normality and homogeneity of variance necessary for an analysis of variance test. In these cases, the data was transformed by calculating the $\log _{10}$ of the original data, and analysis of variance was conducted on the transformed data. Where the transformed data still violated the assumptions of normality and homogeneity of variance, the original, untransformed data were analyzed using Friedman's nonparametric test.

Citrus Agricultural Center ORCHARD FLOOR MANAGEMENT STUDY. Treatments were established in the fall of 1993 in a 3-year-old, flood-irrigated 'Valencia' orange grove planted on 6.7$\mathrm{m}(22-\mathrm{ft})$ centers at the University of Arizona Citrus Agricultural Center,
Waddell, Ariz. Three treatments were arranged in a randomized complete block design with four replications. Buffer tree rows (i.e., trees not included in any treatment) surrounded the experiment and separated each block from other blocks. Each treatment unit consisted of nine trees arranged in a $3 \times 3$ square. The orchard floor management treatments were 1) a 'Salina' strawberry clover crop, 2) mechanically mowed resident weed populations, and 3 ) clean culture with no vegetation (i.e., bare ground) maintained using postemergence herbicides. The strawberry clover and resident weeds occupied about $4.6 \mathrm{~m}(15 \mathrm{ft})$ in the middles between tree rows leaving strips of bare ground about $2.1 \mathrm{~m}(7 \mathrm{ft})$ wide centered on the tree rows. The clean culture treatment and vegetation free tree-row strips in the strawberry clover and resident weed treatments were maintained using hand labor and spot treatments with glyphosate. Glyphosate was applied in a $2 \%$ solution $(\mathrm{v} / \mathrm{v})$ using a hand-held controlled-droplet applicator [Herbi (Micron Sprayers, Bromyard, Herefordshire, U.K.)] on an as needed basis about monthly. The strawberry clover was mowed to remove weeds emerging from the clover canopy. Weeds were mowed so as not to impede harvesting and cultural operations. Mowing occurred in June, then again in October or November of each year. Trees were fertilized annually with $605.2 \mathrm{~kg} \cdot \mathrm{ha}^{-1}(540 \mathrm{lb} / \mathrm{acre})$ nitrogen in the form of ammonium sulfate $(24 \mathrm{~N}-0 \mathrm{P}-0 \mathrm{~K})$, split among three applications.

In this experiment, all the fruit on a tree was picked at the same time and weighed. The 1994-95 harvest was conducted in stages as follows: block 1 on 24 Feb. 1995, block 2 on 2 Mar. 1995 , block 3 on 10 Mar. 1995 and block 4 on 7 Mar. 1995. The 1995-96 and 1996-97 harvests were conducted in a similar sequential fashion. Leaf samples were collected in August 1994 and 1995 from three trees in each treatment in each block and pooled by treatment and block. The analyses of nitrogen, phosphorus, potassium, and sulfurwere conducted as described above for the Yuma Mesa orchard floor management study. Soil samples were collected on 5 Dec. 1996 from the top $0.3 \mathrm{~m}$ ( $1 \mathrm{ft})$ of the soil profile to measure total nitrogen, total organic carbon, and total organic matter in the different orchard floor management treatments. Ten-gram soil samples were air dried, ground with a chain grinder and passed through a 2 -mm (0.08-inch) sieve. The sieved samples were milled in a Spex ball mill (Spex CertiPrep, Matuchen, N.J.). A 4-g (0.14-oz) subsample was treated with $10 \%$ phosphoric acid and oven dried at $80^{\circ} \mathrm{C}\left(176.0^{\circ} \mathrm{F}\right)$ for $48 \mathrm{~h}$ to remove inorganic carbon for the determination of organic carbon and organic matter (Artiola, 1990). The remaining sample was analyzed for total nitrogen content. Samples were analyzed for total organic carbon and nitrogen by high temperature combustion using a nitrogen, carbon, and sulfur analyzer (model 1500; Carlo Erba Reagenti, Rodano, Italy) (Artiola, 1990). Organic matter content for these samples was calculated using the method of Page et al. (1982). Untransformed yield, leaf analysis and soil sample data were analyzed using analysis of variance tests and means separation tests using the SPSS statistical package.

\section{Results and discussion}

Yuma Mesa orchard floor manAGEMENT STUDY. Weed populations changed within a year of the implementation of the various orchard floor management strategies as illustrated by the percentage ground cover data for some of the more common weeds (Figs. 1 and 2). The population levels of all weed species were very low in the clean culture treatment indicating the efficacy of the herbicide treatments. Similar herbicide effectiveness has been reported in experiments conducted in Florida citrus groves (Singh et al., 1990). The percentage ground cover of bermudagrass remained very low in the clean culture plots because oryzalin and norflurazon killed most emerging seedlings and the postemergence applications of sethoxydim controlled the established plants (Ross and Lembi, 1999) (Fig. 1). Purple nutsedge control in the clean culture treatment was due primarily to the preemergence use of norflurazon and postemergence spot treatments of glyphosate (Ross and Lembi, 1999) (Fig. 1).

Low rate applications of glyphosate in the chemical mow treatment were not effective in controlling many weed species and the populations of several undesirable weed species such as bermudagrass and purple nutsedge began to increase (data not shown). In addition, rank growth of weeds began to restrict access to the treatment plots 


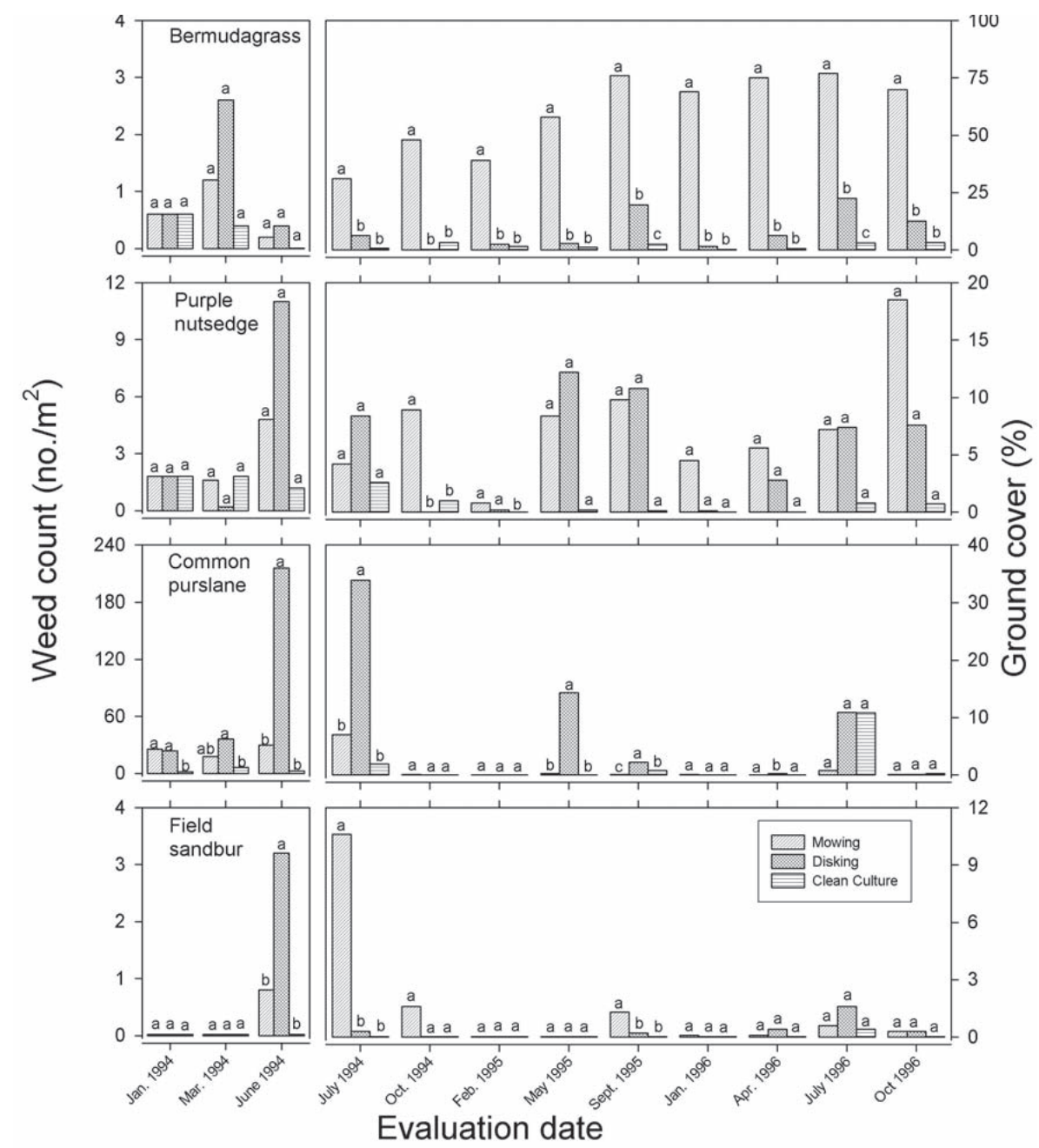

Fig. 1. Effect of mowing, disking, or herbicide applications on the weed populations on the Yuma Mesa (Yuma, Ariz.) expressed as weed counts or percentage ground cover for some common summer weeds: bermudagrass (Cynodon dactylon), purple nutsedge (Cyperus rotundus), common purslane (Portulaca olevacea), and field sandbur (Cenchrus pauciflorus). Weed count data [plants per $0.5 \mathrm{~m}^{2}$ $\left(5.38 \mathrm{ft}^{2}\right)$ ] was collected through June 1994 and beginning in July 1994, weed populations were quantified by visually estimating the percent ground cover of each species in a $37.2-\mathrm{m}^{2}\left(400-\mathrm{ft}^{2}\right)$ area enclosed by four trees. Bars with the same letter on the same date and for the same species were not significantly different according to the Student-Newman-Keuls test at $P=0.05$.

and hinder additional chemical mow applications; therefore, we terminated this treatment. Emergence and establishment of strawberry clover was unsuccessful, probably due to the rapid drying of the sandy soil surface after irrigation, the inability to frequently irrigate due to scheduling restrictions imposed by the irrigation district and possibly due to poor seed quality.

Disking suppressed bermudagrass in the area between tree rows although ground cover increased in the intervals between disking operations and during the summer, as can been seen from the data collected in the first half of 1996 (Fig. 1). The bermudagrass plants present under the canopy of the trees in the disk treatment were not contacted by the disk and provided a source for reinfestation. Similarly, purple nutsedge ground cover increased during the summer months between disking operations as shown by the data collected in July 1994, May 1995, September 1995, and July 1996 (Fig. 1). The disruption of apical dominance by disking that stimulates the growth of shoots from previously dormant tubers (Holm et al., 1977) and the rapid growth rate of purple nutsedge, resulted in rapid reinfestation of disked areas during the summer. Bermudagrass ground cover rapidly increased in the mow treatment over the course of this experiment (Fig. 1). Bermudagrass became the domi- nant weed in the mow treatment and it appeared that it would eventually completely cover the ground in this treatment if this experiment had been continued. Other warm season species that increased in the mow treatment were field sandbur (Cenchrus panciflo$r u s$ ) and purple nutsedge although their population numbers were still lower than bermudagrass (Fig. 1). Mowing of middles in Florida citrus groves was also found to perpetuate the presence of bermudagrass and other monocot species (Tucker et al., 1997).

Comparison of the disk and mow treatments indicated that mowing suppressed broadleaf weeds compared to grasses and purple nutsedge. For example, common purslane (Portulaca oleracea) covered $34 \%$ of the ground in the disk treatment but only $7 \%$ in the mow treatment in July 1994, and covered $11 \%$ of the ground in the disk treatment versus $1 \%$ in the mow treatment in July 1996 (Fig. 1). Similarly, the percentage ground cover of two winter weed species, london rocket (Sisymbrium irio) in February 1995, and annual sowthistle (Sonchus oleraceus) in February 1995 and April 1996 were significantly greater in the disk treatment than in the mow treatment (Fig. 2). The populations of broadleaf weeds such as common purslane in the summer [Fig. I (July 1994, May 1995, and July 1996)], and london rocket and annual sowthistle in the winter [Fig. 2 (February 1995 and April 1996)], rapidly increased in the disk treatment between disking operations. Grass and nutsedge species are more tolerant of mowing because their meristems are near the ground at the base of the shoots, whereas the meristems of broadleaf weeds are at the apex of the shoots and are removed by the mower (Ross and Lembi, 1999). In addition, as the amount of space occupied by bermudagrass and purple nutsedge increased, the opportunity for broadleaf weeds to become established in the mow treatment decreased [Figs. 1 and 2 (January 1996 and April 1996)].

There were no significant yield differences among orchard floor management treatments for the 1994-95 season (Table 2). The 1995-96 and 1996-97 treatment yields showed that the yield of the clean culture treatment was significantly greater than either the mow or the disk treatments (Table 2). Jordan (1981) obtained similar results in a 'Valencia' orange grove where 


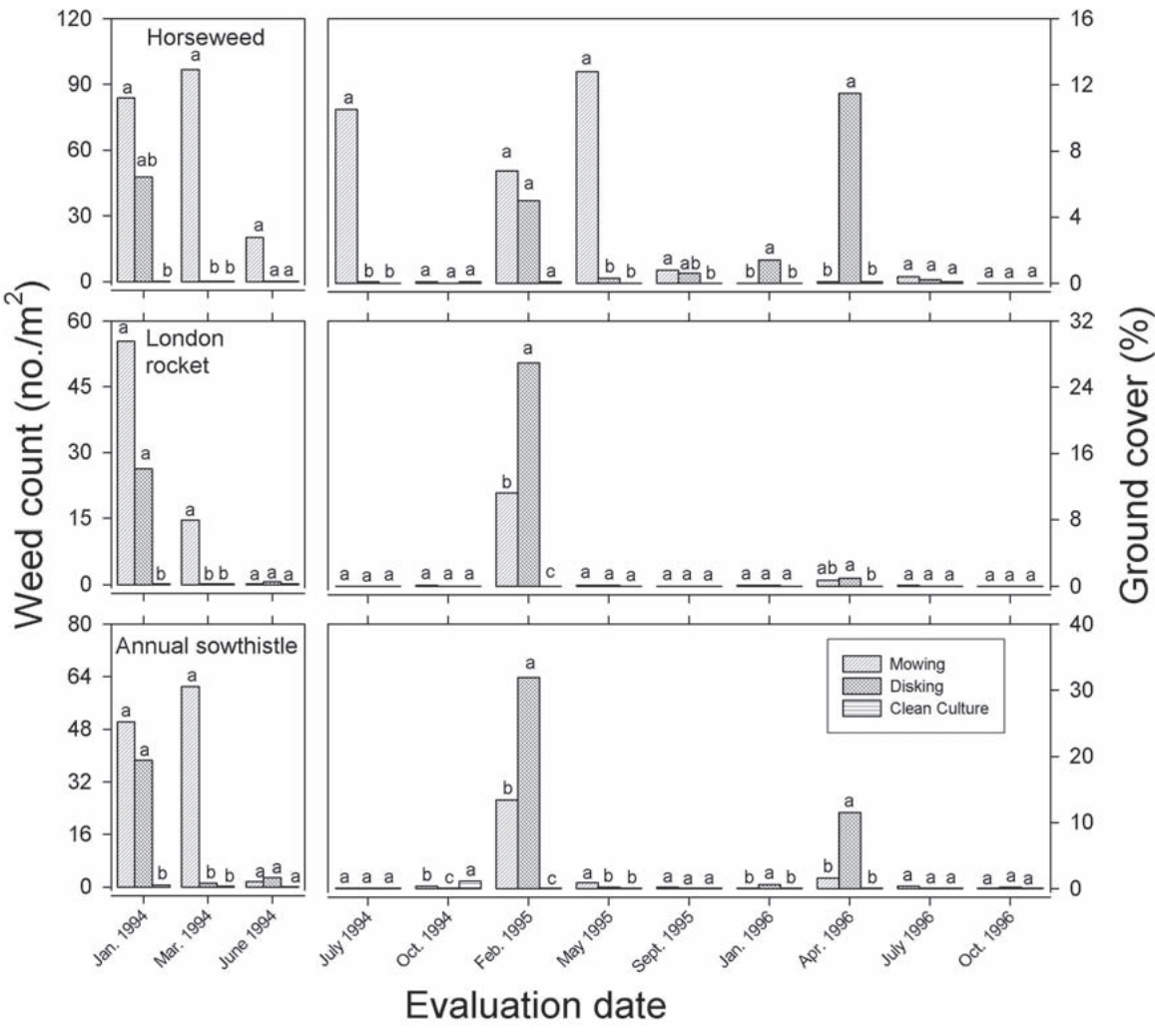

Fig. 2. Effect of mowing, disking, or herbicide applications on the weed populations on the Yuma Mesa (Yuma, Ariz.) expressed as weed counts or percentage ground cover for some common cool season weeds: horseweed (Conyza canadensis), london rocket (Sisymbrium irio), and annual sowthistle (Sonchus oleraceus). Weed count data [plants per $0.5 \mathrm{~m}^{2}\left(5.38 \mathrm{ft}^{2}\right)$ ] were collected through June 1994 and beginning in July 1994, weed populations were quantified by visually estimating the percent ground cover of each species in a $37.2-\mathrm{m}^{2}\left(400-\mathrm{ft}^{2}\right)$ area enclosed by four trees. Bars with the same letter on the same date and for the same species were not significantly different according to the Student-Newman-Keuls test at $\boldsymbol{P}=\mathbf{0 . 0 5}$. man and Rodney (1961) reported, in a 15-year study on 'Marsh' grapefruit (Citrusparadisi) in Arizona, that yields of trees under a nontillage, chemical weed control program was greater than yield of trees under a disking program or yields of trees competing with a bermudagrass sod.

Jordan (1981) found that 'Valencia' orange trees competing with mostly annual weeds (as in the disk treatment of this study) produced more fruit than trees competing with bermudagrass. Thus, we speculate that the lemon yields of the disk treatment might have surpassed the yields of the mow treatment over a longer time period as percentage ground cover increased and the effect of the bermudagrass infestation became more severe.

In addition to greater total yield, trees in the clean culture treatment yielded more fruit at the first (4 Oct. 1995) harvest of the 1995-96 season (Table 3) and the second harvest (6 Dec. 1996) of the 1996-97 season (Table 4). Furthermore, trees in the clean culture treatment yielded more fruit in the 115 (fruit per box) or larger size categories than trees in the disk or mow treatments (Table 5). Similar results occurred during the second harvest of the 1996-97 season with respect to fruit sizes greater than or equal to 140 (Table 6). Although for the 3 Oct. 1996 harvest, mowing and disking led fruit yield was significantly greater when weeds, especially bermudagrass, were completely controlled than when weeds were present. Orchard floor management studies in other tree crops have also measured greater yields in herbicide clean culture treatments compared to other management treatments such as disking or cover crops (Hogue and Neilsen, 1987). The mow and disk treatments were not significantly different from one another although the disk treatment had numerically greater yields in the 1995-96 and 1996-97 harvests. This yield trend was correlated with a greater percentage ground cover of bermudagrass in the mow treatment during the 1995-96 harvest and 1996-97 harvest compared to the 1994-95 harvest. Several studies have documented greater tree vigor, trunk cross-sectional area and yield in disking or cultivation orchard floor management systems compared to grass sod (Hogue and Neilsen, 1987). Hilge-
Table 2. Total annual and cumulative yield of lemon trees in the mow, disk, and clean culture treatments used to manage orchard floor vegetation at the Yuma Mesa (Yuma, Ariz.) experiment.

\begin{tabular}{|c|c|c|c|c|}
\hline Treatment & $\begin{array}{c}\text { Total } \\
1994-95 \\
\left(\mathrm{~kg}^{\mathrm{z}} / \mathrm{tree}\right)\end{array}$ & $\begin{array}{c}\text { Total } \\
1995-96 \\
\text { (kg/tree) }\end{array}$ & $\begin{array}{c}\text { Total } \\
1996-97 \\
\text { (kg/tree) }\end{array}$ & $\begin{array}{c}\text { Cumulative } \\
\text { total } \\
1994-97 \\
\text { (kg/tree) } \\
\end{array}$ \\
\hline Mowing & $106.1 \pm 17.4 \mathrm{a}^{\mathrm{y}}$ & $162.2 \pm 16.7 b$ & $51.6 \pm 11.1 \mathrm{~b}$ & $320.0 \pm 32.2 \mathrm{~b}$ \\
\hline Disking & $100.4 \pm 7.3 \mathrm{a}$ & $173.9 \pm 13.8 b$ & $57.9 \pm 16.5 b$ & $332.1 \pm 16.9 b$ \\
\hline Clean culture & $115.7 \pm 11.9 \mathrm{a}$ & $201.4 \pm 12.8 \mathrm{a}$ & $67.4 \pm 10.7 \mathrm{a}$ & $384.6 \pm 15.7 a$ \\
\hline
\end{tabular}

Values are means \pm standard deviations of four blocks with 30 trees per plot. Values within a column followed by the same letter are not significantly different according to the Student-Newman-Keuls test at $P=0.05$.

Table 3. Lemon tree yield ${ }^{\mathrm{z}}$ by picking date for the 1995-96 harvest in the mow, disk, and clean culture orchard floor vegetation management treatments at the Yuma Mesa (Yuma, Ariz.) experiment.

\begin{tabular}{lccc}
\hline Treatment & $\begin{array}{c}\text { 4 Oct. } 1995 \\
\left(\mathrm{~kg}^{\mathrm{z}} / \text { tree }\right)\end{array}$ & $\begin{array}{c}\text { 12 Dec. } 1995 \\
(\mathrm{~kg} / \text { tree })\end{array}$ & $\begin{array}{c}28 \mathrm{Feb} .1996 \\
(\mathbf{k g} / \text { tree })\end{array}$ \\
\hline Mowing & $15.1 \pm 5.8 \mathrm{~b}^{\mathrm{y}}$ & $55.8 \pm 11.8 \mathrm{a}$ & $91.3 \pm 12.4 \mathrm{a}$ \\
Disking & $22.4 \pm 6.7 \mathrm{~b}$ & $66.9 \pm 3.4 \mathrm{a}$ & $84.6 \pm 15.8 \mathrm{a}$ \\
Clean culture & $35.9 \pm 5.0 \mathrm{a}$ & $74.8 \pm 16.0 \mathrm{a}$ & $90.7 \pm 1.8 \mathrm{a}$ \\
\hline
\end{tabular}

${ }^{\mathrm{z}} 1.0 \mathrm{~kg}=2.20 \mathrm{lb}$.

yalues are means \pm standard deviations of four blocks with 30 trees per plot. Values within a column followed by the same letter are not significantly different according to the Student-Newman-Keuls test at $P=0.05$. 
Table 4. Lemon tree yield by picking date for the 1996-97 harvest in the mow, disk, and clean culture orchard floor vegetation management treatments at the Yuma Mesa (Yuma, Ariz.) experiment.

\begin{tabular}{lcc}
\hline Treatment & $\begin{array}{c}\text { 3 Oct. } \mathbf{1 9 9 6} \\
\left(\mathbf{k g}^{\mathrm{z}} / \text { tree }\right)\end{array}$ & $\begin{array}{c}\text { 6 Dec. } \mathbf{~} 996 \\
(\mathbf{k g} / \text { tree })\end{array}$ \\
\hline Mowing & $8.4 \pm 2.2 \mathrm{a}^{\mathrm{y}}$ & $43.2 \pm 11.3 \mathrm{c}$ \\
Disking & $7.6 \pm 2.6 \mathrm{a}$ & $50.3 \pm 14.4 \mathrm{~b}$ \\
Clean culture & $4.9 \pm 2.2 \mathrm{a}$ & $62.5 \pm 12.8 \mathrm{a}$ \\
\hline${ }^{2} 1.0 \mathrm{~kg}=2.20 \mathrm{lb}$. & & \\
y.Values are means \pm standard deviations of four blocks with 30 trees per plot. Values within a column followed by \\
the same letter are not significantly different according to the Student-Newman-Keuls test at $P=0.05$
\end{tabular}

to larger fruit than did the clean culture treatment, this may be due to the large yield of the 1995-96 season in the clean culture treatment that suppressed early season bloom and fruit sizing the following year. Nonetheless, when the two 1996-97 harvests are combined, the clean culture treatment yielded 23.2 $\mathrm{kg}(5 \mathrm{l} .15 \mathrm{lb})$ per tree of fruit size 140 or greater, compared to $10.5 \mathrm{~kg}(23.15$ lb) per tree for the mow treatment and $16.0 \mathrm{~kg}(35.27 \mathrm{lb})$ per tree for the disk treatment. Since lemon producers typically receive greater returns for fruit harvested early in the season and for large fruit harvested at any time, the greater total yield and larger fruit size in the clean culture treatment has the potential to enhance economic returns to growers relative to the disk or mow orchard floor management schemes.

Competition for nutrients limits crop yield in some agricultural production systems. However, there were no significant differences among treatments in the level of nitrogen, potassium, phosphorous, and sulfur in leaves collected in August 1994 and 1995 (Table 7). Nutrients were within normal ranges suggesting that none of these nutrients were limiting for tree growth or fruit production (Wutscher and Smith, 1993).

Several studies indicate that competition between weeds and trees for water is significant, and may lead to yield losses (Hogue and Neilsen, 1987). Tucker et al. (1997) used 20 soil moisture resistance blocks installed at 15 and $30 \mathrm{~cm}$ (5.9 and 11.8 inches) depths in each treatment middle to measure soil moisture in an almost clean culture treatment achieved through chemical application and mechanical mowing, a mechanical mowing treatment, and a chopping treatment (equivalent to a disking treatment) in a Florida citrus grove. During dry periods, they found there was significantly less soil moisture in the mowing and chopping treatments compared to the intensive clean culture treatment. Weeds present in the former two treatments were using significant amounts of water and competing with the trees for this resource. Unfortunately, Tucker et al. (1997) did not measure tree growth or yield. Jordan (1981) measured soil moisture at 23, 46 and $96 \mathrm{~cm}$ (9.1, 18.1, and 37.8 inches) depths midway between trees at 2 -week intervals using a neutron probe. In general, plots without weeds had significantly more soil moisture than plots with weeds. The soil moisture differences were correlated with 'Valencia' orange leaf water potential measured in a pressure chamber. Both predawn and midday leaf water potentials were significantly more negative in plots with weeds than in plots without weeds. Orchard floor management studies in apple (Malus $\times$ domestica) orchards also found that vegetation on the orchard floor resulted in reduced soil water content compared to cultivated or herbicide clean culture treatments and that these differences were correlated with growth and yield differences (Merwin and Stiles, 1994; Merwin et al., 1994; Walsh et al., 1996).

Table 5. Lemon fruit size in the mow, disk, or clean culture orchard floor management treatments in the first (4 Oct. 1995) and second (12 Dec. 1995) picks of the 1995-96 harvest on the Yuma Mesa (Yuma, Ariz.).

Fruit size [no. fruit per $17-\mathrm{kg}(37.5-1 b)$ box] as a percentage of all fruit harvested

\begin{tabular}{llcrrrrr}
\cline { 3 - 7 } Date & Treatment & $\mathbf{2 0 0}$ & $\mathbf{1 6 5}$ & $\mathbf{1 4 0}$ & $\mathbf{1 1 5}$ & $\mathbf{2 0 5}$ & $\mathbf{1 1 1 5}$ \\
\hline \multirow{2}{*}{ 4 Oct. 1995 } & Mowing & $1.75 \mathrm{a}^{\mathrm{z}}$ & $39.75 \mathrm{a}$ & $46.72 \mathrm{a}$ & $9.80 \mathrm{~b}$ & $1.93 \mathrm{~b}$ & $11.73 \mathrm{~b}$ \\
& Disking & $1.90 \mathrm{a}$ & $37.85 \mathrm{a}$ & $46.67 \mathrm{a}$ & $11.05 \mathrm{~b}$ & $2.50 \mathrm{~b}$ & $13.55 \mathrm{~b}$ \\
& Clean culture & $1.55 \mathrm{a}$ & $30.75 \mathrm{a}$ & $47.85 \mathrm{a}$ & $15.22 \mathrm{a}$ & $4.66 \mathrm{a}$ & $19.88 \mathrm{a}$ \\
\multirow{2}{*}{12 Dec. 1995} & Mowing & $3.42 \mathrm{a}$ & $35.51 \mathrm{a}$ & $28.53 \mathrm{a}$ & $8.39 \mathrm{~b}$ & $1.69 \mathrm{a}$ & $10.08 \mathrm{a}$ \\
& Disking & $2.22 \mathrm{a}$ & $23.47 \mathrm{a}$ & $28.07 \mathrm{a}$ & $26.45 \mathrm{a}$ & $3.81 \mathrm{a}$ & $30.27 \mathrm{a}$ \\
& Clean culture & $5.27 \mathrm{a}$ & $22.61 \mathrm{a}$ & $28.18 \mathrm{a}$ & $14.35 \mathrm{~b}$ & $8.41 \mathrm{a}$ & $22.77 \mathrm{a}$
\end{tabular}

${ }^{2}$ Values are means of four blocks; values within a column for the same harvest date, followed by the same letter are not significantly different according to the Student-NewmanKeuls test at $P=0.05$. Different harvest dates were independently analyzed, so means from the two dates are not comparable.

Table 6. Lemon fruit size in the mow, disk, or clean culture orchard floor management treatments in the first (3 Oct. 1996) and second (6 Dec. 1996) picks of the 1996-97 harvest on the Yuma Mesa (Yuma, Ariz.).

Fruit size [no. fruit per $17-\mathrm{kg}(37.5-1 b)$ box] as a percentage of all fruit harvested

\begin{tabular}{llcccccc}
\cline { 3 - 7 } Date & Treatment & $\mathbf{2 0 0}$ & $\mathbf{1 6 5}$ & $\mathbf{1 4 0}$ & $\mathbf{1 1 5}$ & $\mathbf{9 5}$ & $\mathbf{1 4 0}$ \\
\hline \multirow{2}{*}{ 3 Oct. 1996 } & Mowing & $25.12 \mathrm{a}^{\mathrm{z}}$ & $50.12 \mathrm{a}$ & $18.17 \mathrm{a}$ & $3.05 \mathrm{a}$ & $0.35 \mathrm{a}$ & $21.60 \mathrm{a}$ \\
& Disking & $32.62 \mathrm{a}$ & $44.77 \mathrm{a}$ & $14.62 \mathrm{a}$ & $2.17 \mathrm{ab}$ & $0.20 \mathrm{~b}$ & $17.05 \mathrm{a}$ \\
& Clean culture & $33.37 \mathrm{a}$ & $44.87 \mathrm{a}$ & $13.42 \mathrm{a}$ & $1.70 \mathrm{~b}$ & $0.18 \mathrm{~b}$ & $15.32 \mathrm{a}$ \\
6 Dec. 1996 & Mowing & $21.97 \mathrm{a}$ & $34.90 \mathrm{a}$ & $21.22 \mathrm{c}$ & $2.90 \mathrm{c}$ & $0.17 \mathrm{a}$ & $24.30 \mathrm{c}$ \\
& Disking & $20.17 \mathrm{a}$ & $34.97 \mathrm{a}$ & $25.15 \mathrm{~b}$ & $3.80 \mathrm{~b}$ & $0.25 \mathrm{a}$ & $29.22 \mathrm{~b}$ \\
& Clean culture & $16.92 \mathrm{~b}$ & $34.73 \mathrm{a}$ & $30.35 \mathrm{a}$ & $5.17 \mathrm{a}$ & $0.30 \mathrm{a}$ & $35.85 \mathrm{a}$ \\
\hline
\end{tabular}

${ }^{2}$ Values are means of four blocks; values within a column for the same harvest date, followed by the same letter are not significantly different according to the Student-NewmanKeuls test at $P=0.05$. Different harvest dates were independently analyzed, so means from the two dates are not comparable. 
Table 7. Effect of mowing, disking, or clean culture orchard floor management treatments on the average amount of nitrogen, potassium, phosphorous and sulfur in 'Limoneira 8A Lisbon' lemon leaves on the Yuma Mesa (Yuma, Ariz.). For each nutrient within each year, none of the treatment means were significantly different from other treatments.

\begin{tabular}{llcccc}
\hline Year & Treatment & $\begin{array}{c}\text { Nitrogen } \\
\text { (\% dry wt) }\end{array}$ & $\begin{array}{c}\text { Potassium } \\
\text { (\% dry wt) }\end{array}$ & $\begin{array}{c}\text { Phosphorus } \\
\text { (\% dry wt) }\end{array}$ & $\begin{array}{c}\text { Sulfur } \\
\text { (\% dry wt) }\end{array}$ \\
\hline \multirow{2}{*}{1994} & Mowing & 2.90 & 1.69 & 0.22 & 0.24 \\
& Disking & 2.88 & 1.70 & 0.23 & 0.33 \\
& Clean culture & 2.90 & 1.74 & 0.21 & 0.32 \\
1995 & Chemical mow & 2.83 & 1.64 & 0.21 & 0.25 \\
& Mowing & 2.69 & 2.86 & 0.22 & 1.09 \\
& Disking & 2.73 & 2.94 & 0.22 & 1.20 \\
& Clean culture & 2.59 & 2.87 & 0.21 & 0.99 \\
\hline
\end{tabular}

Table 8. Yield of 'Valencia' oranges in the clean culture, mowed resident weeds, or 'Salina' strawberry clover orchard floor vegetation management treatments at the University of Arizona Citrus Agricultural Center, Waddell.

\begin{tabular}{lcccc}
\hline Treatment & $\begin{array}{c}1994-95 \\
(\mathbf{k g} / \text { tree })\end{array}$ & $\begin{array}{c}1995-96 \\
(\mathbf{k g} / \text { tree })\end{array}$ & $\begin{array}{c}1996-97 \\
(\mathbf{k g} / \text { tree })\end{array}$ & $\begin{array}{c}\text { Cumulative } \\
\text { yield } \\
(\mathbf{k g} / \text { tree })\end{array}$ \\
\hline Clean culture & $29 \pm 9 \mathrm{a}^{\mathrm{z}}$ & $52 \pm 17 \mathrm{a}$ & $50 \pm 17 \mathrm{a}$ & $131 \pm 36 \mathrm{a}$ \\
Resident weeds & $27 \pm 10 \mathrm{a}$ & $40 \pm 11 \mathrm{~b}$ & $43 \pm 22 \mathrm{a}$ & $110 \pm 35 \mathrm{~b}$ \\
Strawberry clover & $26 \pm 9 \mathrm{a}$ & $45 \pm 17 \mathrm{ab}$ & $43 \pm 15 \mathrm{a}$ & $115 \pm 37 \mathrm{ab}$ \\
\hline
\end{tabular}

${ }^{2}$ Values are means \pm standard deviation of four blocks with nine trees per plot. Values within a column followed by the same letter are not significantly different according to the Student-Newman-Keuls test at $P=0.05$.

Table 9. Effect of the clean culture, mowed resident weeds, or 'Salina' strawberry clover orchard floor vegetation management treatments on total soil nitrogen, total soil organic carbon, and total soil organic matter at the University of Arizona Citrus Agricultural Center, Waddell after 3 years. Samples were taken in tree middles in Dec. 1996.

\begin{tabular}{lccc}
\hline & $\begin{array}{c}\text { Total } \\
\text { soil } \\
\text { nitrogen } \\
\text { Treatment }\end{array}$ & $\begin{array}{c}\text { Total } \\
\text { organic } \\
\text { carbon } \\
{\left[\mathrm{mg} \cdot \mathrm{kg}^{-1}(\mathrm{ppm})\right]}\end{array}$ & $\begin{array}{c}\text { Total } \\
\text { organic } \\
\text { matter }\end{array}$ \\
\hline Clean culture & $\left.367 \pm 65 \mathrm{~b}^{\mathrm{z}} \cdot \mathrm{kg}^{-1}(\mathrm{ppm})\right]$ & $0.247 \pm 0.035 \mathrm{c}$ & $0.493 \pm 0.069 \mathrm{c}$ \\
Resident weeds & $\left.433 \pm 65 \mathrm{~b} \cdot \mathrm{kg}^{-1}(\mathrm{ppm})\right]$ \\
Strawberry clover & $567 \pm 98 \mathrm{a}$ & $0.345 \pm 0.042 \mathrm{~b}$ & $0.690 \pm 0.084 \mathrm{~b}$ \\
\hline 2Vlo & $0.452 \pm 0.089 \mathrm{a}$ & $0.903 \pm 0.174 \mathrm{a}$ \\
\hline
\end{tabular}

${ }^{2}$ Values are means \pm standard deviation of four blocks. Values within a column followed by the same letter are not significantly different according to the Student-Newman-Keuls test at $P=0.05$.

Competition for water may not be the only cause of reduced yield in this study. Shallow root pruning, as occurred in the disk treatments, would be expected to reduce water absorption and increase tree stress (Parker et al., 1993). Allelopathy may also partially account for the success of bermudagrass, in interactions with other plant species, particularly in the mow treatment. Smith et al. (2001) found that when seedling pecans (Carya illinoensis) were irrigated with bermudagrass leachate, total seedling dry weight was reduced by about 16\%. Although presumably bermudagrass would not be as detrimental to mature trees, an allelopathic effect cannot be ignored. Thus, the lower lemon yields of the disk and the mow orchard floor management treatments on the Yuma Mesa may have been due to allelopathy, competition for water and damage to shallow roots in the disk treatments.

Citrus Agricultural Center orCHARD FLOOR MANAGEMENT STUDY. Analysis of the winter 1994-95 'Valencia' orange harvest data found no significant differences among the three orchard floor management treatments (Table 8). The large within-treatment variation in the 1994-95 yield data was due to vigor differences between trees caused by their young age and varying degrees of frost injury sustained in 1992. The 1994-95 harvest data were also considered preliminary because the strawberry clover cover crop was not well established until early 1995. The 1995-96 harvest data and the 3-year cumulative yield data indicate that tree yields in the clean culture treatment were greater than yields in the mowed resident weed treatment (Table 8). This result is consistent with the yield differences measured between the clean culture and mow treatments in the Yuma Mesa experiment, the other citrus experiments discussed above and many other orchard floor management studies (Hogue and Neilsen, 1987). The major weeds in the mowed resident weed plots were barnyard grass (Echinochloa crus-galli), mexican sprangletop (Leptochloa uninerva), horseweed (Conyza canadensis), and prostrate pigweed (Amaranthus blitoides) in the spring, summer and fall and annual sowthistle (Sonchus oleraceus) in the winter. Bermudagrass was not present at this study site. Trees in the 'Salina' strawberry clover cover crop treatment had an average yield that was intermediate between and not significantly different from either the clean culture or the mowed resident weed treatment yields (Table 8 ).

Soil samples collected in Dec. 1996 showed that the resident weed and strawberry clover treatments had a beneficial impact on soil characteristics (Table 9). The strawberry clover treatment had significantly more total soil nitrogen, total organic carbon, and total organic matter than either the resident weed or the clean culture treatments. The resident weed treatment had intermediate amounts of organic carbon and organic matter but did not have significantly more soil nitrogen than the clean culture treatment. Although there were differences between treatments in total soil nitrogen levels, there were no significant differences among treatments in the level of nitrogen in the leaf samples collected in August 1994 and 1995 (Table 10). There were also no differences in potassium, phosphorus, and sulfur content of the leaf samples and none of the four nutrients were limiting for tree growth or fruit production (Table 10). These results are similar to those found in other orchard floor management studies where both legume and nonlegume cover crops increase soil nitrogen and organic matter but it was often difficult to measure differences in nutrient levels among treatments (Hogue and Neilsen, 1987). These results were also similar to those discussed in the Yuma Mesa experiment and suggest that water was probably the limiting resource that impacted yield. However, the improvement of soil characteristics and the intermediate yield of the straw- 
Table 10. Effect of the clean culture, mowed resident weeds, or 'Salina' strawberry clover orchard floor vegetation management treatments on the average amounts of nitrogen, potassium, phosphorous and sulfur in 'Valencia' orange leaves collected in August at the University of Arizona Citrus Agricultural Center, Waddell. For each nutrient within each year, none of the treatment means were significantly different from the other treatments.

\begin{tabular}{llcccc}
\hline Year & Treatment & $\begin{array}{c}\text { Nitrogen } \\
\text { (\% dry wt) }\end{array}$ & $\begin{array}{c}\text { Potassium } \\
\text { (\% dry wt) }\end{array}$ & $\begin{array}{c}\text { Phosphorus } \\
\text { (\% dry wt) }\end{array}$ & $\begin{array}{c}\text { Sulfur } \\
\text { (\% dry wt) }\end{array}$ \\
\hline \multirow{2}{*}{1994} & Clean culture & 2.81 & 1.70 & 0.20 & 1.08 \\
& Resident weeds & 2.60 & 1.63 & 0.19 & 0.99 \\
& Strawberry clover & 2.50 & 1.64 & 0.21 & 0.31 \\
& Clean culture & 3.46 & 2.64 & 0.31 \\
& Resident weeds & 3.64 & 2.80 & 0.42 \\
& Strawberry clover & 3.37 & 2.84 & 0.31 \\
\hline
\end{tabular}

berry clover treatment (which was not significantly different from the clean culture yield) offer encouragement that better irrigation management might avoid tree water stress and result in higher yields although it is often difficult to compensate for the water and nutrients used by cover crops (Hogue and Neilsen, 1987). Another benefit of the strawberry clover treatment observed in this experiment was effective suppression of resident weed species similar to that noted for other legume species (Ross et al., 2001). Other potential benefits include reduction in canopy temperatures. (Hogue and Neilsen, 1987; McCloskey et al., 1996; Walsh et al., 1996). Reduced canopy temperature may reduce physiological fruit abscission, which is most severe when leaf temperatures are high (Davies and Albrigo, 1994). Reduced canopy temperatures may also increase the amount of carbohydrates available for fruit production by increasing the amount of photosynthetically fixed carbon and by decreasing the amount of carbon respired at night (Syvertson and Lloyd, 1994). All these factors may have compensated for the competition for water between the trees and the clover. Alternatively, there was little numerical difference between the resident weed and clover treatment tree yields over the course of this study, and it is possible that a prolonged study would have resulted in no yield difference between those two treatments.

In both studies it appeared that the yield reductions caused by resident weed populations could be avoided by removing the weeds using herbicides. While mowing or disking suppressed broadleaf weeds or grasses and sedges, respectively, these management practices resulted in significant yield reductions in both the Yuma Mesa study and the CAC study. Finally, in situations where light was not limiting for tree growth and none of the nutrients tested appeared to be limiting, it appeared that any treatment that reduced water availability to citrus trees reduced yield.

\section{Literature cited}

Altieri, M.A. and L.L. Schmidt. 1986. Cover crops affect insect and spider populations in apple orchards. Calif. Agr. 40:15-17.

Artiola, J.F. 1990. Determination of carbon, nitrogen, and sulfur in soils, sediments, and wastes: A comparative study. Intl. J. Environ. Anal. Chem. 41:159-171.

Barmore, R.L. 1980. Soil survey of YumaWellton area, parts of Yuma County, Arizona and Imperial County, California. U.S. Soil Conserv. Serv., Ariz. Agr. Expt. Sta., Calif. Agr. Expt. Sta., Wash., D.C.

Bordelon, B.P. and S.C. Weller. 1997. Preplant cover crops affect weed and vine growth in first-year vineyards. HortScience 32:1040-1043.

Bradshaw, L. and W.T. Lanini. 1995. Use of perennial cover crops to suppress weeds in Nicaraguan coffee orchards. Intl. J. Pest Mgt. 41:185-194.

Bugg, R.L., M. Sarrantonio, J.D. Dutcher, and S.C. Phatak. 1991. Understory cover crops in pecan orchards: Possible management systems. Amer. J. Alt. Agr. 6:50-62.

Davies, F. and L.G. Albrigo. 1994. Citrus. Crop production science in horticulture series. vol. 2. CAB Intl., Wallingford, U.K.

Gomez, J.A., F. Orgaz, F.J. Villalobos, and E. Fereres. 2002. Analysis of the effects of soil management on runoff generation in olive orchards using a physically based model. Soil Use Mgt. 18:191-198.

Grafton-Cardwell, E.E., Y. Ouyang, and R.L. Bugg. 1999. Leguminous cover crops to enhance population development of Euseius tularensis (Acari: Phytoseiidae) in citrus. Biol. Control 16:73-80.

Hilgeman, R.H. and D.R. Rodney. 1961. Commercial citrus production in Arizona. Univ. Ariz. Agr. Expt. Sta. Coop. Ext. Serv. Spec. Rpt. 7.
Hogue, E.J. and G.H. Nielsen. 1987. Orchard floor vegetation management. Hort. Rev. 9:377-430.

Holm, L.G., D.L. Plucknett, J.V. Pancho, and J.B. Herberger. 1977. The world's worst weeds: Distribution and biology. Univ. Press Hawaii, Honolulu.

Jackson, M.L. 1958. Soil chemical analysis. Prentice-Hall, Englewood Cliffs, N.J.

Jordan, L.S. 1981. Weeds affect citrus growth, physiology, yield, fruit quality. Proc. Intl. Soc. Citricult. 2:481-483.

Jordan, L.S. and B.E. Day. 1973. Weed control in citrus, p. 82-97. In: W. Reuther (ed.). The citrus industry. vol. 3. Univ. Calif. Press, Berkeley, Calif.

Knapp,J.L. 1999. Citrus commodity: A biologic and economic assessment of pesticide usage. Natl. Agr. Pesticide Impact Assessment Progr. Rpt. 1-CA-99. Univ. Fla. Inst. Food Agr. Sci., Gainesville.

Marks, C.F., W.J. Saidak, and P.W. Johnson. 1973. Effects of soil management on numbers of root-lesion nematode Pratylenchus penetrans in soils of Ontario peach orchards. Can. J. Plant Sci. 53:181-185.

Marsh, K.B., M. J. Daly, and T. P. McCarthy. 1996. The effect of understory management on soil fertility, tree nutrition, fruit production and apple fruit quality. Biol. Agr. Hort. 13:161-173.

Matheron, M., M. Maurer, and M. Porchas. 1998. Improving management and control of fungal diseases affecting Arizona citrus trees, 1997, p. 43-49. In: G. Wright and M. Kilby (eds.). 1998 Citrus and deciduous fruit and nut research report. College Agr. Ser. P-113. Univ. Ariz., Tucson.

McCloskey, W.B. and M. Maurer. 1997. Effects of long-term preemergence herbicide use on growth and yield of citrus, $\mathrm{p}$. 114-117. In: G. Wright (ed.). 1997 Citrus research report. College Agr. Ser. P-109. Univ. Ariz., Tucson.

McCloskey, W.B. and G.C. Wright. 1999. Applying Roundup to the base oflemon tree canopies: Effects on leaves, flowers, fruitlets, and yield, p. 39-57. In: G. Wright and M. 
Kilby (eds.). 1999 Citrus and deciduous fruit and nut research report. College Agr. Ser. P-117. Univ. Ariz., Tucson.

McCloskey, W.B., G.C. Wright, and K.C. Taylor. 1996. Managing vegetation on the orchard floor in flood-irrigated Arizona citrus groves, p. 58-77. In: G. Wright (ed.). 1996 Citrus research report. College Agr. Ser. P-105. Univ. Ariz., Tucson.

Metcalf, R.L. and R.A. Metcalf. 1993. Destructive and useful insects: Their habits and control. $5^{\text {th }}$ ed. McGraw Hill, New York.

Merwin, I.A. and W.C. Stiles. 1994. Orchard groundcover management impacts on apple tree growth and yield, and nutrient availability and uptake. J. Amer. Soc. Hort. Sci. 119:209-215.

Merwin, I.A., W.C. Stiles, and H.M. van Es. 1994. Orchard groundcover management impacts on soil physical properties. J. Amer. Soc. Hort. Sci. 119:216-222.

Mitchell, H.L. 1972. Micro determination of nitrogen in plant tissues. J. AOAC. 55: $1-3$.

Page, A.L., R.H. Miller, and D.R. Keeny. 1982. Methods of soil analysis. Part 2. Chemical and microbiological properties, p. 574. In: Agronomy (9). 2nd ed. Amer. Soc. Agron., Soil Sci. Soc. Amer., Madison, Wis.

Parker, M.L., J. Hull, and R.L. Perry. 1993. Orchard floor management affects peach rooting. J. Amer. Soc. Hort. Sci. 118:714-718.

Perkin-Elmer. 1982. Analysis of plant tissue: Wet digestion. Perkin-Elmer Agr. Appl. AY5:1-3. Perkin-Elmer Anal. Instr., Shelton, Conn.

Roberson, E.B., S. Sarig, and M.K. Firestone. 1991. Cover crop management of polysaccharide-mediated aggregation in an orchard soil. Soil Sci. Soc. Amer. J. 55: 734-739.

Ross, S.M., J.R. King, R.C. Izaurralde, and J.T. Donovan. 2001. Weed suppression by seven clover species. Agron. J. 93: 820-827.
Ross, M.A. and C.A. Lembi. 1999. Applied weed science. $2^{\text {nd }}$ ed. Prentice Hall, Upper Saddle River, N.J.

Sainju, U.M. and B.P. Singh. 1997. Winter cover crops for sustainable agricultural systems: influence on soil properties, water quality, and crop yields. HortScience 32 : 21-28.

Singh, M., D.P.H. Tucker, and S.H. Futch. 1990. Multiple applications of preemergence herbicide tank mixtures in young citrus groves. Proc. Fla. State Hort. Soc. 103:16-21.

Smith, M.W., M.E. Wolf, B.S. Cheary, and B.L. Carroll. 2001. Allelopathy of bermudagrass, tall fescue, redroot pigweed and cutleaf evening primrose on pecan. HortScience 36:1047-1048.

Syvertson, J.P. and J.J. Lloyd. 1994. Citrus, p. 65-100. In: B. Schaffer and P.C. Anderson (eds.). Handbook of environmental physiology of fruit crops. vol. 2. Subtropical and tropical crops. CRC Press Inc., Boca Raton, Fla.

Teasdale, J.R. 1996. Contribution of cover crops to weed management in sustainable agricultural systems. J. Prod. Agr. 9: 475-479.

Tedders, W.L. 1983. Insect management in deciduous orchard ecosystems: habitat manipulation. Environ. Mgt. 7:29-34.

Tucker, D.P.H., C.G. Erickson, and K.T. Morgan. 1997. Middles management methods in citrus affect soil moisture retention and vegetation species. Proc. Fla. State Hort. Soc. 110:39-43.

Walsh, B.D., S. Salmins, D.J. Buszard, and A.F. MacKenzie. 1996. Impact of soil management systems on organic dwarf apple orchards and soil aggregate stability, bulk density, temperature and water content. Can. J. Soil Sci. 76:203-209.

Wutscher, H.K. and P.F. Smith. 1993. Citrus, p. 165-170. In: W.F. Bennett (ed.). Nutrient deficiencies and toxicities in crop plants. APS Press, St. Paul, Minn.

\section{Variety, Shading, and Growth Stage Effects on Pigment Concentrations in Lettuce Grown under Contrasting Temperature Regimens}

\author{
Matthew D. Kleinhenz, ${ }^{1,3}$ \\ Darla G. French, ${ }^{2}$ \\ Aparna Gazula, ${ }^{1}$ and \\ Joseph C. Scheerens ${ }^{1}$
}

Additional INDEX WORDS. Lactuca sativa, light intensity, anthocyanin, antioxidant, chlorophyll, 'Galactic', 'Green Vision', greenhouse, leaf color, 'New Red Fire', quality, 'Rolina', stress

Summary. Shading effects on chlorophyll a (ChlA), chlorophyll b (ChlB) and anthocyanin (Antho) concentrations were examined at three developmental stages in four varieties of lettuce (Lactuca sativa) grown under contrasting temperature regimens in the greenhouse. Seedlings were transplanted to pots and grown at $\mathbf{3 0}$

${ }^{\circ} \mathrm{C}\left(86.0^{\circ} \mathrm{F}\right) \mathrm{day} /$ night $(\mathrm{D} / \mathrm{N})$ (Study 1) or $30 / 18{ }^{\circ} \mathrm{C}\left(86.0 / 64.4^{\circ} \mathrm{F}\right) \mathrm{D} / \mathrm{N}$ (Study 2). One-half of all plants in each study were positioned under bottomless shade boxes which reduced

The many important contributions of Brenda Schult, Lee Duncan, Kim Hershberger, and Glen Cassidy are gratefully acknowledged. We thank Peter Ling, Michelle Jones, and Annette Wszelaki for their critical reading of the manuscript and Geza Hrazdina, Cornell University, for supplying cyanidin 3 -glucoside chloride. Manuscript number HCS03-12. Salaries and research support provided in part by State and Federal funds appropriated to the Ohio Agricultural Research and Development Center, The Ohio State University. Work also supported in part by the College of Wooster and with grants from the Ohio Agricultural Research and Development Center and Ohio Vegetable and Small Fruit Research and Development program. Use of trade names does not imply endorsement of the products named nor criticism of similar ones not named.

${ }^{1}$ Department of Horticulture and Crop Science, The Ohio State University, Ohio Agricultural Research and Development Center (OARDC), 1680 Madison Avenue, Wooster, Ohio 44691-4096.

${ }^{2}$ Graduate student, Agricultural Education, Purdue University, West Lafayette, Indiana. Formerly, undergraduate student, College of Wooster, Wooster, Ohio. Work described herein was completed as part of the Independent Study requirement at the College of Wooster.

${ }^{3}$ Corresponding author; e-mail kleinhenz@osu.edu. 